\title{
SOCIAL DOMINANCE ORIENTATION AND TRUST IN INSTITUTIONS AMONG MACEDONIAN AND ALBANIAN YOUNG ADULTS ${ }^{1}$
}

\author{
Ana Fritzhand, ${ }^{2} \mathrm{PhD}$. \\ Faculty of Philosophy, Institute of Psychology, Skopje, Macedonia \\ anaf@fzf.ukim.edu.mk \\ Biljana Blazevska - Stoilkovska, PhD. \\ Faculty of Philosophy, Institute of Psychology, Skopje, Macedonia \\ biljanabs@yahoo.com
}

\begin{abstract}
This study analyzes the relationship between social dominance orientation and trust in institutions among young adults of Macedonian and Albanian ethnicity. Total number of 133 respondents (78 Macedonians and 55 Albanians), from 20 until 30 years of age, with different levels of education (finished high school, students/graduated and higher), participated in the research. Macedonians are all declared as Orthodox Christians, while Albanians are all declared as Muslims. All participants are from Skopje and currently live in the capital. Findings are mostly in line with the results from other similar studies. It could be plausible that Macedonian young adults are more oriented towards social dominance, since they belong to the majority group. However, those who trust more the education system are less socially dominant. On the other side, regarding social dominance orientation, Albanians are less socially dominant and this is probably because they

\footnotetext{
${ }^{1}$ This research is part of the project "From inclusive Identities to Inclusive Societies: Exploring Complex Social Identity in Western Balkans", funded by RRPP and the Swiss Agency for Development and Cooperation. The results in this paper were presented at the international conference "Contemporary Security Paradigms and Challenges: Theory and Practice", in Ohrid, Macedonia, 18-19 September 2015

${ }^{2}$ Corresponding author: Ana Fritzhand, PhD. (anaf@fzf.ukim.edu.mk)
} 


\section{Securuility}

represent the minority group. In terms of trust in institutions, Albanian young adults are more prone to trust religious institutions, as well as media, EU and health care system. As for Macedonians, they have more trust in the Macedonian Army, although such difference is not very strong. Findings are further discussed and elaborated in terms of their importance and applicability.

Keywords. social dominance orientation, trust in institutions,

Macedonians, Albanians, young adults

\section{Апстракт}

Во трудот се анализира поврзаноста помеѓу ориентацијата кон социјална доминација и довербата во институциите, кај млади возрасни со Македонска и Албанска етничка припадност. Со истражувањето се опфатени 133 испитаници (78 Македонци и 55 Албанци), на возраст од 20 до 30 години, со различен степен на образование (завршено средно образвание, студенти/дипломирани и повисоко). Сите испитаници Македонци се со Православна вероисповест, додека Албанците се декларирани како Муслимани. Потекнуваат од Скопје и во моментот на истражувањето живеат во главниот град. Добиените резултати се согласни со резултатите од други слични истражувања. Македонците покажуваат поголема ориентираност кон социјална доминација со оглед на тоа што припаѓаат на мнозинската група во државата. Сепак, оние кои повеќе им веруваат на образовните институции се помалку ориентирани кон социјална доминација. Што се однесува до Албанците, кај нив е регистрирана пониска ориентација кон социјална доминација, што најверојатно се должи на нивната припадност кон малцинството. Во поглед на довербата во институциите, Албанците значително повеќе им веруваат на религиските институции, медиумите, ЕУ и здравствениот систем. Македонците, пак, повеќе веруваат во Армијата на Р. Македонија, но добиената разлика, иако значајна, не е многу голема. Резултатите понатаму се дискутираат и елаборираат во насока на нивната важност и практична применливост.

Клучни зборови: ориентација кон социјална доминација, доверба во институции, Македонци, Албанци, млади возрасни 


\section{Security}

\section{Introduction}

The concept of social dominance orientation is probably one of the most widely used individual differences measure in studying generalized prejudices (Kugler, Cooper, and Nosek, 2010). It is mostly elaborated in Social Dominance Theory, which was initially created to better understand the mechanisms of formation and maintenance of group-based social hierarchy. This theory applies multilevel analysis while describing human societies as systems and focusing on understanding the processes that contribute to emergence and maintenance of prejudices (Pratto, Sidanius, \& Levin, 2006).

Social dominance is perceived as people's tendency to form group-based social hierarchies which are maintained by social policies and practices as well as by cooperative behavior manifested by group members with high- and low-status. This means that those who are more socially dominant have greater benefits such as resources, power, wealth, access to better education, health care and housing etc., compared to others who belong to subordinate groups. According to Social Dominance Theory, there are three distinctive systems of group-based social hierarchy i.e. age, gender and arbitrary-set system, which represent universal trimorphic form of human societies yet variable depending on the characteristics of each society (both internally over time and across different societies). Authors further argue that these three systems differ qualitatively, especially in terms of flexibility, level of violence and focus. This theory also emphasize that group-based social hierarchies are predominantly generated by the complex forms of discrimination both on individual and group levels as well as institutions (Pratto, Sidanius, \& Levin, 2006).

Trust in institutions plays crucial role in every democratic society. It is usually described as the extent to which people expects from institutions to successfully fulfill their expected roles (Rothstein, 2005; Hudson, 2006; according to Castillo, Miranda, \& Torres, 2011). Therefore, the more citizens trust in public institutions such as the parliament, the government and so on, the more they will be motivated to be involved in the public life and by that will sustain the democratic processes in the country. Trust in institutions is sometimes called "vertical" and differs from "horizontal" which is defined as interpersonal, emphasizing individual differences in personality. In terms of its relation to social dominance orientation, some studies (ex. Castillo, Miranda, \& Torres, 2011) suggest that higher levels of social dominance (as well as authoritarianism) strongly predict the trust in government, political parties and army. 


\section{Security}

As far as authors of this paper are informed, in R. of Macedonia the research that analyze the relationship between social dominance orientation and trust in institution in young adults from different ethnicities are very scarce. Therefore, the focus in this paper is on correlation and differences between these two variables analyzed separately and in comparison for groups of Macedonians and Albanians. The reason we analyze these particular ethnic groups is because Republic of Macedonia, however young in its independence as a state, invested significant effort in the processes for peace and democracy building, especially after the conflict between Macedonians and Albanians, in 2001. Although democratic participation is guaranteed for every citizen in the country, it does not look like it is always practiced (Fritzhand \& Petrovic, 2014). Therefore, it is important to see how high is the level of social dominance and the trust in institutions among young adults in R. of Macedonia, in order to be able to give more precise suggestions for future research and interventions.

\section{Social dominance orientation: theoretical overview and empirical findings}

Social Dominance Orientation (SDO) is defined as "a general attitudinal orientation toward intergroup relations, reflecting whether one generally prefers such relations to be equal, versus hierarchical" (Pratto et al., 1994, p.742). Some authors (ex. Altemeyer, 1998; according to Akrami, \& Ekehammar, 2006), suggest that SD0 mostly refers to authoritarian dominance, i.e. some research find positive correlation between authoritarianism and social dominance orientation (ex. Henry, Sidanius, Levin, Pratto, \& Nammour, 2003). Other authors (ex. Pratto et al., 1994), state that SDO differ from authoritarianism, as well as from interpersonal dominance and conservativism. It also shows negative correlation with empathy, tolerance, altruism and communality (Pratto et al., 1994).

As mentioned in the introduction, SDO is mostly elaborated in Social Dominance Theory. This theory emphasizes the underlying set of effects of discrimination on individual and group levels. Discrimination can be introduced through institutions (usually those who enhance hierarchy), for example, by providing more benefits and goods to dominant groups than to subordinate groups. On the opposite, institutions that are classified as "hierarchyattenuating", promote human and civil rights and liberties, and are oriented towards equality, helping the less fortunate ones, those who are often oppressed and vulnerable. However, discrimination can also be recognized on individual level both in institutions and 


\section{Security}

outside of them. Here, social structure of the institution, as well as the structure of the whole society, plays an important role. Following this, for example, rich people have more resources to offer to the poor ones (if they are willing to), but also have more power to influence big corporations and important policy makers to make decisions which will correspond to their needs and not the needs of all citizens in the society (including those who belong to the subordinate groups). Another example (and the effect) of discrimination is segregation in the society and gender role differentiation (Pratto, Sidanius, \& Levin, 2006).

According to Morrison \& Ybarra (2008), it can be expected that SDO will increase if individuals (especially those who are highly identified with their in-group and are ready to protect it), perceive a realistic threat, or obstacles to the position of their in-group and to the general wellbeing. Morrison, Fast, \& Ybarra (2009) also present data according to which perception of intergroup threat among highly identified group members moderates the relation between group status and SDO.

The socialization process and the role models a child is exposed to early in life, have strong influence on how it's ideological points of view will be shaped later when he/she grow up. This is so because the children judge the world through the lenses of cognitively and morally lower stages of development. However, under the parental and peer influence, in the period of adolescence, these ideological perspectives are being formed and positioned in more precise ways. This is how SDO, among other constructs that shape ideological frameworks, is being established and organized (Altemeyer, 1981; according to Heaven, Ciarrochi, \& Leeson, 2011). Recent findings about children's social identity, morality and social exclusion reflect on developmental processes that underlie children's capability to both challenge and reinforce prejudices and stereotypes. In other words, if moral judgments are not presented during development of children's social identity, they will justify exclusion of their peers holding on prejudice and discrimination. Nevertheless, if moral values such as fairness, justice, equality etc. are in the basis of their understanding of group dynamics, they will be more willing to reject and challenge prejudicial/stereotypic beliefs and expectations (Killen \& Rutland, 2011).

Relevant research on this topic (ex. Ekehammar et al., 2004; McFarland, 1998; Akrami, Ekehammar, \& Araya, 2000; according to Akrami, \& Ekehammar, 2006), provide data that those who score higher on SDO are usually characterized with, so called, generalized prejudice and hold more negative attitudes towards different social groups. In particular, it is related to negative attitudes toward socially subordinate groups who have 


\section{Security}

low power and status (Duckitt, 2006). Furthermore, individuals with higher SDO usually prefer professional roles that enhance hierarchy. $0 \mathrm{n}$ the other side, findings are completely opposite for those with low SDO (Pratto et al., 1994). Similar results report Lalonde et al. (2007), who provide evidence that high SDO is significantly negatively related to hierarchyattenuating beliefs (ex. attitudes towards interracial dating), and strongly positively related to hierarchy-enhancing beliefs (ex. stereotyping of interracial relationships).

Concerning gender differences, men are more prone to social dominance compared to women (ex. Dambrun, Duarte, \& Guimond, 2004; Huang \& Liu, 2005; Pratto et al., 1994). In terms of social and political ideologies, there is a proven correlation between SDO and support of group-based hierarchy as well as war, civil rights and other policies that impact intergroup relations in various ways (Pratto et al., 1994). In one recent study conducted in Croatia (Maričić, Franc, \& Šakić, 2008) authors found that opposition to equality is higher among males, less religious and right politically oriented people. Results from the same study show that higher group-based dominance orientation is more characteristic for the group of participants with low income and low educational level, as well as for older age and males.

\section{Trust in institutions}

Trust in institutions is mostly elaborated in sociological studies and in political science, but there are some important aspects which are analyzed in psychological theory and research as well. When discussing trust in general terms, there is one important distinction between horizonta/ and vertica/trust - first one being defined as trust in other people and the second as trust in institutions. Thus, sociology is usually oriented towards analyzing the horizontal type of trust when studying social cohesion, while political science mostly focus its research on vertical trust and how much it impacts the society - more specifically, the democracy in the society (Castillo, Miranda, \& Torres, 2011).

Concerning the origins of trust in institutions, according to Aleksovska (2014), there are mainly two theoretical frameworks - cultural theories and institutional theories which explain the origins of trust starting from competing positions. Basically, cultural theories incorporate bottom-up approach and highlight early socialization process and cultural norms as determinants of trust. Here, there is a strong link between social and institutional trust. Although there are number of studies which support this position, there 


\section{Security}

are also studies (ex. Newton, 2001; as cited in Aleksovska, 2014) which provide data that such link is mediated by the effectiveness of social and political institutions. On the other side, institutional (or performance) theories are using top-down approach by viewing institutional trust as a result of institutional performance, i.e. individual decide on the amount of trust he/she will give to the political institutions, based on the level of their performance. Nevertheless, whether these theories will or will not have their practical application in different social contexts, depends on the specifics of the context (i.e. the society) itself.

Relevant literature reveals that there are many definitions of trust. Here, we are focusing on trust in institutions that can be conceptualized (this is mostly true for the public institutions), as the "extent to which institutions are expected to carry on their expected role satisfactorily" (Rothstein, 2005; Hudson, 2006; as cited in Castillo, Miranda, $\&$ Torres, 2011). How successful these public institutions are in fulfilling their expected roles (especially when it comes to specific public institutions such as the parliament, or the government, or army etc.), is defined through democratic and/or justice principles. However, there are other factors that influence trust in institutions that has to do with how many resources a person poses, the levels of perceived threat and also with personal judgment whether one is competent to face those threats and deal with them (Ross \& Mirowsky, 2006; as cited in Castillo, Miranda, \& Torres, 2011).

In that sense, the less number of resources someone has, when faced with perceived threat, the less his/her trust in institutions will be, since one perceives himself/herself as less capable of facing and dealing with the threat (Ross \& Mirowsky, 2006; as cited in Castillo, Miranda, \& Torres, 2011). It is also proved that people evaluate and therefore trust (or do not trust) the institutions holding on their personal set of values and beliefs (Gabriel, 1995; as cited in Castillo, Miranda, \& Torres, 2011) acquired during socialization processes (Hardin, 2001; as cited in Castillo, Miranda, \& Torres, 2011). Another factor that influence this trust, is the perception of competitiveness and social danger through the experiences of keeping the trust or loosing the trust in social interactions on daily bases (Sibley \& Duckitt, 2009; Yamagishi, 2001; as cited in Castillo, Miranda, \& Torres, 2011).

Recently, there is an increase of research on trust in institutions due to several reasons. One is that the level of institutional trust in developed Western societies declines over years (Dalton, 2004; Pharr and Putnam, 2000; Norris, 1999; as cited in Aleksovska, 2014). The other is that in countries from Central and Eastern Europe which are recognized 


\section{Security}

as "new democracies" there is generally low trust in institutions (Mishler and Rose, 1997, 2001; Lovell, 2001; Boda and Medve-Balint, 2012; as cited in Aleksovska, 2014). Hence, latest data according to Edelman Trust Barometer 2016, indicate that in 2016 (compared to 2015) overall trust in government slightly increases in some countries (ex. Canada, Ireland, USA, Turkey etc.), but decreases in others (ex. Germany, Poland, France, Brazil etc.). Same is true for the trust in media and in NGO's (with some exemptions).

Regarding the trust in institutions in R. of Macedonia data published in the latest issue of Bertelsmann Stiftung, BT/2016-Macedonia Country Report, show lower trust in institutions and their democratic capacities among citizens. These data are reported according to the survey done by the Institute for Democracy "Societas Civilis" in 2011. More precisely they found lower level of trust in the government (42\%), president (39\%), parliament (32\%) and judiciary (28\%) than in police (45\%) and the army $(56 \%)$. Trust in the international community was relatively high $(41 \%)$ compared to domestic democratic institutions. Democratic scores and regime ratings presented in the Freedom House Report for Macedonia for 2015 indicate that in terms of independence of media, national democratic governance, judicial framework and independence and corruption. the climate in the R. of Macedonia is closer to authoritarian than to democratic. Aleksovska (2014), analyze the development of trust in institutions in Macedonia in the timeframe from 1998 until 2013 and report several main findings. First, overall trust in institutions increases significantly after Ohrid Framework Agreement in 2001 (especially for ethnic Albanians). Second, the strongest predictor of trust in institutions is support for one of the parties in the leading coalition. Lastly, after 2008 (especially among ethnic Albanians) there is a decline in trust in institutions but positive effects from the Ohrid Framework Agreement remain notable.

\section{Methodology}

Present research is part of a bigger project applied in Western Balkan Countries (i.e. in Serbia, Bosnia and Herzegovina, Kosovo and Macedonia). Its main idea is to explore complex social identity of young people who live in this part of the world and see how such identity correlates with a set of variables describing its complexity and inclusiveness. The aim of present research, however, is to analyze how social dominance orientation correlates with the trust in different institutions (separately for Macedonians and for Albanians) as 


\section{Securitity}

well as to see how these two groups of participants differ in terms of both mentioned variables.

Total number of 133 respondents (78 Macedonians and 55 Albanians), from 20 until 30 years of age, with different levels of education (finished high school, students/graduated and higher) are included in this research. All Macedonians are declared as Orthodox Christians. Albanians are all declared as Muslims. Participants are from Skopje and currently live in the capital.

Social dominance orientation was measured using Social Dominance Orientation Questionnaire (Pratto, 2014). Participants were asked to rate how much they support or oppose 4 statements about groups in general, on a scale from 1 - Extremely Oppose to 11 Extremely Favour. Trust in institutions was measured using a list of 13 institutions (both domestic and international), where respondents were asked to answer how much they trust each of those institutions. Participants rated each institution on a scale from 1 - None at all, to 5 - Completely. Institutions included in the present research were: religious institutions, army, education system, media, police, Parliament, EU, NATO, UN, health care system, justice system, political parties, and the Government (source European Values Study).

\section{Results}

Pearson's coefficients of correlation between social dominance orientation and trust in institutions were calculated separately for Macedonian and for Albanian participants. The results for Macedonian young adults indicate that there is only one statistically significant correlation (negative), between social dominance orientation and education system, which means that the more they trust in education system, the less they are oriented towards social dominance (see Table 1). For the Albanians, social dominance orientation was significantly and positively correlated with religious institutions, Army, and the Parliament (see Table 2). This means that the more they trust in religious institutions, or in the Army, or the Parliament, the more they are oriented towards social dominance. 
Sécuurity
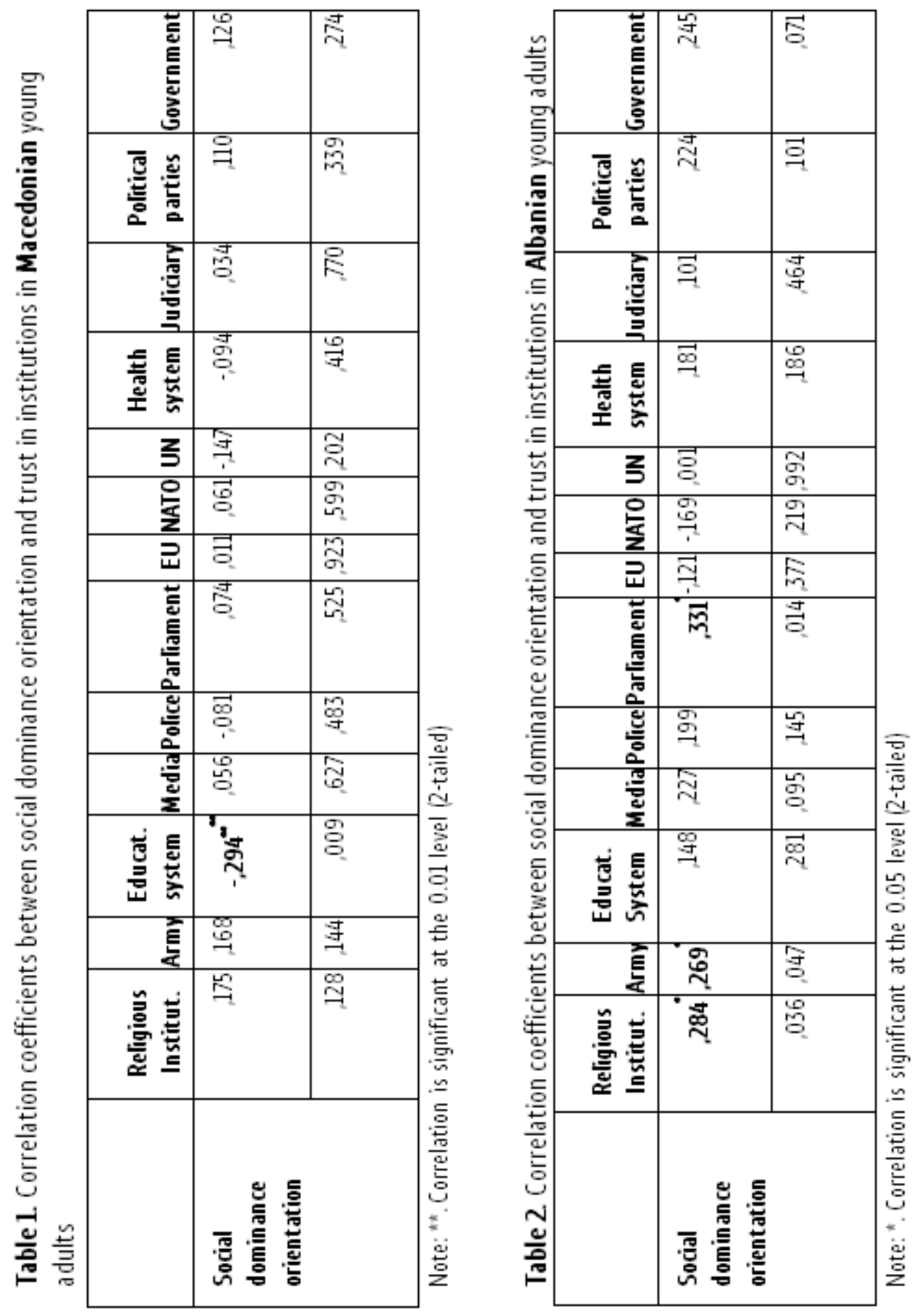


\section{Secuurity}

Further analyzes revealed that there are also statistically significant differences between Macedonian and Albanian young adults in terms of social dominance orientation and trust in institutions. In terms of social dominance orientation Macedonians scored significantly higher $(t / 11)=2.69 ; \mathrm{p}<0,01)$ compared to Albanians. Considering the trust in institutions differences were registered for religious institutions $(t / 111)=-4.43 ; p<0,01)$, army $(t / 11)=1.98 p<0,05)$, media $(t / 11)=-2.74 ; p<0,01), E U(t / 11)=-2.05 ; p<0,05)$, and the health care system $(t / 11)=-2.63 ; p<0,01)$. In all comparisons (except for army) Albanians were scoring higher than Macedonians, indicating that they trust these institutions significantly more (see Table 3).

Table 3. Differences between Macedonian and Albanian young adults in terms of social dominance orientation and trust in institutions

\begin{tabular}{|c|c|c|c|c|c|c|}
\hline Ethnicity & & N & Mean & Std. Dev. & t-test & $\mathrm{p}$ \\
\hline Religious institutions & $\begin{array}{r}\text { MAC } \\
\text { ALB }\end{array}$ & $\begin{array}{l}78 \\
55\end{array}$ & $\begin{array}{l}2,18 \\
3,11\end{array}$ & $\begin{array}{l}1,155 \\
1,227\end{array}$ & $-4,429$ &, 000 \\
\hline Army & $\begin{array}{r}\text { MAC } \\
\text { ALB }\end{array}$ & $\begin{array}{l}78 \\
55\end{array}$ & $\begin{array}{l}2,71 \\
2,31\end{array}$ & $\begin{array}{l}1,157 \\
1,169\end{array}$ & 1,976 & 050 \\
\hline Education system & $\begin{array}{l}\text { MAC } \\
\text { ALB }\end{array}$ & $\begin{array}{l}78 \\
55\end{array}$ & $\begin{array}{l}2,68 \\
2,87\end{array}$ & $\begin{array}{l}1,069 \\
1,248\end{array}$ &,- 975 &, 331 \\
\hline Media & $\begin{array}{l}\text { MAC } \\
\text { ALB }\end{array}$ & $\begin{array}{l}78 \\
55\end{array}$ & $\begin{array}{l}1,86 \\
2,36\end{array}$ & $\begin{array}{l}, 899 \\
1,223\end{array}$ & $-2,743$ & ,007 \\
\hline Police & $\begin{array}{r}\text { MAC } \\
\text { ALB }\end{array}$ & $\begin{array}{l}78 \\
55\end{array}$ & $\begin{array}{l}2,34 \\
2,29\end{array}$ & $\begin{array}{l}1,046 \\
1,133\end{array}$ & 244 & 807 \\
\hline Parliament & $\begin{array}{r}\text { MAC } \\
\text { ALB }\end{array}$ & $\begin{array}{l}78 \\
55\end{array}$ & $\begin{array}{l}1,77 \\
1,93\end{array}$ & $\begin{array}{c}958 \\
1,016\end{array}$ &,- 928 &, 355 \\
\hline EU & $\begin{array}{r}\text { MAC } \\
\text { ALB }\end{array}$ & $\begin{array}{l}78 \\
55\end{array}$ & $\begin{array}{l}2,43 \\
2,87\end{array}$ & $\begin{array}{l}1,251 \\
1,187\end{array}$ & $-2,054$ &, 042 \\
\hline NATO & $\begin{array}{r}\text { MAC } \\
\text { ALB }\end{array}$ & $\begin{array}{l}78 \\
55\end{array}$ & $\begin{array}{l}2,32 \\
2,69\end{array}$ & $\begin{array}{l}1,208 \\
1,136\end{array}$ & $-1,760$ & ,081 \\
\hline
\end{tabular}


Seccurity

\begin{tabular}{|lc|c|c|c|c|c|}
\hline UN & MAC & 78 & 2,43 & 1,186 & $-1,439$ &, 153 \\
& ALB & 55 & 2,73 & 1,162 & & \\
\hline \multirow{2}{*}{ Health care system } & MAC & 78 & 2,40 & 1,042 & $-2,627$ & \multirow{2}{*}{, 010} \\
& ALB & 55 & 2,91 & 1,159 & & \\
\hline \multirow{2}{*}{ Judiciary } & MAC & 78 & 2,08 & 1,023 &,- 931 & \multirow{2}{*}{, 353} \\
& ALB & 55 & 2,25 & 1,142 & & \\
\hline \multirow{2}{*}{ Political parties } & MAC & 78 & 1,71 & 1,011 &,- 174 & \multirow{2}{*}{, 862} \\
& ALB & 55 & 1,75 & 1,022 & & \\
\hline \multirow{2}{*}{ Government } & MAC & 78 & 1,92 & 1,133 & \multirow{2}{*}{, 737} & \multirow{2}{*}{, 462} \\
& ALB & 55 & 1,78 &, 994 & & \\
\hline \multirow{2}{*}{ SDO } & MAC & 78 & 18,3974 & 8,70787 & 2,698 & \multirow{2}{*}{, 008} \\
& ALB & 55 & 14,5091 & 7,37833 & & \\
\hline
\end{tabular}

\section{Discussion and conclusion}

Results from the present study indicate that there are correlations between studied concepts in each analyzed group of participants but also differences between these groups in terms of two main variables - social dominance orientation and trust in institutions. Previous review of theoretical frameworks and the empirical findings show that our results are mostly in line with the results from other similar studies. Regarding correlations, in Macedonian sample those who have higher trust in education system, are less oriented towards social dominance. This is understandable since the more one is informed and has greater knowledge about the "other", about how different societies and people living in them could be, the more one is prone to cooperate, to be more openminded and inclusive - thus, less socially dominant. Having in mind that the age range of participants is 20-30 years, and that many of them are students (or have finished their studies) also contribute to such result. This means that education could be a corner-stone for overcoming segregation and other negative side-effects from high social dominance in the society. In the case of R. of Macedonia, which is multicultural and mutiethnical society, mentioned findings recommend further investment in educational system, in order to 


\section{Security}

promote inclusiveness and to decrease the potential tendency for social dominance among youth.

As for the Albanians, social dominance orientation was significantly correlated with religious institutions, army, and the parliament. This means that the more they trust these institutions, the more they are oriented towards social dominance. Mentioned results are in line with some of the studies presented in the theoretical part of this paper. Some authors (ex. Pratto et al., 1994), emphasize that individuals with higher SDO usually prefer professional roles that enhance hierarchy. In this case all three institutions symbolically represent power and hierarchy, which are usually linked to authoritarian framework. Therefore, the more one trust these institutions and identifies with their symbolism, the more likely is that he/she will be more socially dominant. As shown in other relevant studies (ex. Henry, Sidanius, Levin, Pratto, \& Nammour, 2003), there is positive correlation between authoritarianism and social dominance orientation. It is also presented in the Freedom House Report for Macedonia for 2015, that the climate in the R. of Macedonia is closer to authoritarian than to democratic, in terms of independence of media, national democratic governance, judicial framework and independence and corruption. Finally, there might be some specific cultural characteristics that support such orientation.

However, if we look into differences between Macedonian and Albanian young adults in terms of social dominance orientation, we will find that Macedonians are scoring significantly higher compared to Albanians on this variable. Mentioned difference could be explained with the fact that young adults from Macedonian ethnicity are more socially dominant due to their position as majority in the society. Same could be considered as an explanation of the results for the Albanians regarding their less socially dominant orientation, since they represent the minority group. Macedonia is a country where ethnic Macedonians represent two-thirds or $64 \%$ of population of 2 millions, while ethnic Albanians represent one quarter, or $25 \%$ of the total population. In general, there is a connection between ethnicity and religion of Macedonians and Albanians in Macedonia. The majority of the ethnic Macedonians are Orthodox Christians, whereas the majority of the ethnic Albanians are mainly Muslims (Pajaziti, 2012).

In terms of trust in institutions it is obvious that Albanians are more prone to trust religious institutions, as well as media, EU and health care system. As for Macedonians, they have more trust in the Macedonian army, although such difference is rather weak. Findings for Albanian young adults are understandable because religious identity is very strong among them and that is not the case for Macedonians (whose religious identification 


\section{Security}

is average). Some of the studies conducted in R. of Macedonia (ех. Блажевска-Стоилковска, 2012; Кениг, 2006) indicate that while Albanians are more collectivistic, Macedonians are somewhere in the middle on the collectivism-individualism continuum. Thus, when collectivism was examined among Macedonian young adults, findings showed that higher orientation to collectivism was related to stronger ethnic and religious identification (Кениг, 2003). Furthermore, after the Ohrid Framework Agreement from 2001, Albanians gained more rights and were more included in the society on various levels (Aleksovska, 2014), so that might be the reason why their trust in health care system or the media is higher compared to Macedonians. Concerning EU trust, all Albanian political parties clearly state that one of their goals is entering the EU - a point that probably explains higher trust in EU from the Albanian side in this research. As mentioned previously, Macedonians trust the army slightly more than Albanians probably due to their stronger identification with the state i.e. R. of Macedonia. This finding could also be understood as the result of their perception that the army will keep them safe in case of armed conflict (which might be the consequence from the conflict in 2001). Having in mind that Macedonians are also more oriented towards social dominance than Albanians, it is obvious that such result is in line with some studies (ex. Castillo, Miranda, \& Torres, 2011) which suggest that higher levels of social dominance (as well as authoritarianism) strongly predict the trust in government, political parties and army.

There are, of course, certain limitations of this study. First one is related to the sample. Here, we analyze answers of respondents only from Skopje so larger sample, with participants from other cities from Macedonia should be included in future studies. Diversity of the sample is also an issue. Data are collected from young Macedonians and Albanians and we need more diverse population which will consist of representatives of other ethnic groups, in order to be able to generalize our conclusions more firmly. Another limitation is that the target group in this study is young adults, which means that data are valid only for this particular age group. In further analyzes older and younger participants should also be included. Concerning the trust in institutions, it is possible that respondents exaggerated with their level of pessimism that is not in complete accordance with reality. On the other hand, some of them maybe responded in socially desirable way, which could also alter the results. Furthermore, some variables couldn't be controlled, since the respondents were not willing to share the requested information. Finally, there could be possible shortcomings from the instruments that could affect the data we analyze in this study. 


\section{Security}

\section{Bibliography}

1. Akramy, N. \& Ekehammar, B. (2006). Right-Wing Authoritarianism and Social Dominance Orientation. Their Roots in Big-Five Personality Factors and Facets. Journal of Individual Differences, 27, 3, 1-10, Hogrefe \& Huber Pub.

2. Aleksovska, M. (2014). Trust in Changing institutions. Effects of the Ohrid Framework Agreement on the institutional trust in Macedonia. Deffended Master thesis. Budapest, Hungary.

3. Блажевска Стоилковска, Б. (2012). Донесување одлука за избор на занимањето при премин од средно кон високо образование: неодлучност при изборот и фази во одлучувањето. Необјавена докторска дисертација. Филозофски факултет, Скопје.

4. Castillo, J.C., Miranda, D., \& Torres, P. (2011). Authoritarianism, social dominance and trust in public institutions. TECHNICAL REPORTS MIDE UC. Faculty of social sciences, School of Psychology, Chile

5. Dambrun, M., Duarte, S., \& Guimond, S. (2004). Why are men more likely to support group-based dominance than women? The mediating role of gender identification. British Journal of Social Psychology, 43, 287-297, The British Psychological Society

6. Duckitt, J. (2006). Differential Effects of Right Wing Authoritarianism and Social Dominance Orientation on Out group Attitudes and Their Mediation by Threat From and Competitiveness to Outgroups. Personality and Social Psychology Bulletin, 32, 5, 684-696, Society for Personality and Social Psychology, Inc. USA

7. Fritzhand, A. \& Petrovic, N. (2014). The Culture of Peace: Students' Perception of the Emotional Climate in the Republic of Macedonia. Безбедносни дијалози, 5, 1, 145-162, ISSN 1857-7172 Скопје: Филозофски факултет

8. Heaven, P. C. L., Ciarrochi, J. \& Leeson, P. (2011). Cognitive ability, right-wing authoritarianism, and social dominance orientation: a five-year longitudinal study amongst adolescents. Intelligence, 39, 1, 15-21,

9. Henry, P.J.; Sidanius, J.; Levin, S.; Pratto, F.; \& Nammour, D. (2003). Social Dominance Orientation, Authoritarianism, Religious Identification and Support for Terrorism in the Middle East. Russell Sage Foundation, NY

10. Huang, L.L. \& Liu, H. J. (2005). Personality and social structural implications of the situational priming of social dominance orientation. Personality and Individual Differences, 38, 267-276 Elsevier Pub. 


\section{Security}

11. Кениг, Н. (2006). Хофстедовиот модел на димензии на културата: можности за мерење во групен и индивидуален контекст. Необјавена докторска дисертација. Филозофски факултет, Скопје.

12. Кениг, Н. (2003). Етничкиот идентитет и персоналната ориентација: поврзаност меѓу димензијата колективизам-индивидуализам, вреднувањето на етничките симболи и емпатската идентификација. Годишен Зборник на Филозофскиот факултет, 56, 195-210.

13. Killen, M. \& Rutland, A. (2011). Children and Social Exclusion. Morality, Prejudice, and Group /dentity. Willey-Blackwell Pub., UK

14. Kugler, M.B., Cooper, J., \& Nosek, B. A. (2010). Group-Based Dominance and Opposition to Equality Correspond to Different Psychological Motives. Social Justice Research, 23, 117-155, Springer, USA

15. Lalonde, N.R., Giguere, B., Fontaine, M., \& Smith, A. (2007). Social Dominance Orientation and Ideological Asymmetry in Relation to Interracial Dating and Transracial Adoption in Canada. Journal of Cross-Cultural Psychology, 38, 5, 559572, SAGE Pub., USA

16. Maričić, J.; Franc, R.; \& Šakić, V. (2008). Dimensionality and correlates of the Social Dominance Orientation scale on Croatian sample. Paper presented at XXIX International Congress of Psychology, July 25-28, Berlin, Germany

17. Pratto, F., Sidanius, J., \& Levin, S. (2006). Social dominance theory and the dynamics of intergroup relations: Taking stock and looking forward. European Review of Social Psychology, 17, 271-320. Psychology Press, Taylor and Francis Group, USA

18. Pratto, F., Sidanius, J., Stallworth, L.M., \& Mall, B.F. (1994). Social Dominance Orientation: A Personality Variable Predicting Social and Political Attitudes. Journal of Personality and Social Psychology, 67, 4, 741-763, APA Inc.

19. Michinov, N., Dambrun, M., Guimond, S., \& Meot, A. (2005). Social dominance orientation, prejudice, and discrimination: A new computer-based method for studying discriminatory behaviors. Behavior Research Methods, 37, 1, 91-98, Psychonomic Society, Inc.

20. Pajaziti, A. (2012). Culture and the Quality of Life: the Case of Macedonia. Skopje: Logos-A. 


\section{Securuity}

21. Rios Morrison, K. \& Ybarra, 0. (2008). The effects of realistic threat and group identiWcation on social dominance orientation. Journal of Experimental Social Psychology, 44, 156-163, Elsevier Pub., USA

22. Rios Morrison, K., Fast, J.N., \& Ybarra, 0. (2009). Group status, perceptions of threat, and support for social inequality. Journal of Experimental Social Psychology, 45, 204-210, Elsevier Pub., USA

23. Sidanius, J., Pratto, F., van Laar, C., \& Levin, S. (2004). Social Dominance Theory: Its Agenda and Method. Political Psychology, 25, 6, 845-880, International Society of Political Psychology, Blackwell Pub., USA

Internet resources:

24. BTI 2016 - Macedonia Country Report - Transformation Index (BTI) (visited on May $20^{\text {th }}$ 2016: https://www.btiproject.org/fileadmin/files/BTI/Downloads/Reports/2016/pdf/BTI_2016_Macedoni a.pdf

25. 2016 Edelman Trust Barometer. Annual Global Study (visited on May $20^{\text {th }} 2016$ : http://www.edelman.com/insights/intellectual-property/2016-edelman-trustbarometer/)

26. Freedom House Report - Macedonia (visited on May 20 2016 : https://freedomhouse.org/report/nations-transit/2015/macedonia) 